Renata Chrzanowska

ORCID: https://orcid.org/0000-0002-0901-1043

The Pontifical University of John Paul II in Krakow, Poland

\title{
Remote Teaching of Religious Education in Polish Schools as a Form of Evangelization and Catechesis during the Epidemic Threat
}

\begin{abstract}
This article discusses the current situation of the Church resulting from the epidemic threat of the coronavirus. It indicates how we can teach religious education online, using particular platforms and educational websites, as well as instant messengers and other internet services, to make them tools of catechesis and evangelization. The author emphasizes the spiritual contact of the faithful who, through the media, can participate in Holy Masses and receive the Spiritual Communion. She underlines the role of the proper use of mass media in the work of catechesis and evangelization. The author encourages people responsible for catechesis to be creative in the remote proclamation of the redemptive message, and to use all the available didactic resources and methods.
\end{abstract}

\section{Keywords}

Catechesis, evangelization, remote teaching of religious education, epidemic threat, coronavirus. 


\section{Introduction}

In 1990 religious education returned to Polish schools. This was the opportunity for the Church to discuss the shape of catechesis in Poland. The following documents dedicated to this topic were issued by the Polish bishops: Dyrektorium katechetyczne Kościoła katolickiego w Polsce [The Catechetical Directory of the Catholic Church in Poland]', Podstawa programowa katechezy Kościoła katolickiego [The Core Curriculum for the Catechesis of the Catholic Church] ${ }^{2}$ and Program nauczania religii rzymskokatolickiej w szkołach i przedszkolach [The Curriculum for Teaching Roman Catholic Religious Education in Schools and Preschools]. ${ }^{3}$ In these documents, recognizing the need to reform catechesis and referring to the teaching of the Second Vatican Council, ${ }^{4}$ the bishops presented the role of school as a place to reinforce the cultural and national identity, helping the family in teaching and comprehensively developing a young person, searching for the entire truth about man, and helping the person to be rooted in a world of values.

Almost thirty years have passed from since then. Due to the fact that young people have the access to religious education at schools, they have been given support in growing in the world of values and in broadly understood personal development, which includes spiritual, moral and intellectual aspects. Religion teachers have made every effort to make the lessons of religious education a school catechesis that comprised evangelization elements focused not only on children and youth, but also on their parents.

After thirty years of its introduction in schools, religious education is facing a new challenge - remote teaching. This situation has been caused by the world epidemic threat related to the new coronavirus COVID-19.

The long presence of catechesis in the Polish school environment and the current situation of the epidemic threat make us reflect on the way in which remote lessons of religious education can become the place for evangelization

\footnotetext{
${ }^{1}$ Polish Episcopal Conference, Dyrektorium katechetyczne Kościoła katolickiego w Polsce, Kraków 2001.

${ }^{2}$ Polish Episcopal Conference, Podstawa programowa katechezy Kościoła katolickiego w Polsce, Kraków 2001.

${ }^{3}$ The Commission for Catholic Education of the Polish Episcopal Conference, Program nauczania religii rzymskokatolickiej w szkołach i przedszkolach, Kraków 2001.

${ }^{4}$ Second Vatican Council, Declaration on Christian Education Gravissimum educationis, 5, in: Sobór Watykański II. Konstytucje, dekrety, deklaracje, Poznań 2002, pp. 314-324.
} 
and catechesis. Also, it is worth noting the difference between evangelization and catechesis, and to refer to multimedia didactic resources that may help us spread religious content in the contemporary school and family environment.

\section{Evangelization and catechesis}

While considering the role of religious education at school in the context of evangelization, first we need to explain what evangelization and catechesis are. Defining both concepts shall help us understand the relations between them.

The word evangelization originates from the Greek noun euangelion, i.e. a good message, good news, or from the verb euangelidzein - to bring good news, to announce, to proclaim, to evangelize. ${ }^{5}$ In the words of Pope Paul VI: "Thus it has been possible to define evangelization in terms of proclaiming Christ to those who do not know Him, of preaching, of catechesis, of conferring Baptism and the other sacraments". ${ }^{6}$ Evangelization is a multi-faceted process which consists of several elements that complement and improve one another, among which the Pope enumerates "the renewal of humanity, witness, explicit proclamation, inner adherence, entry into the community, acceptance of signs, apostolic initiative"' In the current situation of the epidemic threat, evangelization becomes a task to be fulfilled by all Christians who, through the witness of their life, proclaim Christ in their everyday life. ${ }^{8}$ It is because the modern world needs witnesses more than teachers. ${ }^{9}$

Catechesis results from evangelization, as it is one of the most important tasks Jesus gave to the Apostles: "Go, therefore, make disciples of all nations, baptizing them in the name of the Father and of the Son and of the Holy Spirit,

Cf. A. Lewek, Nowa ewangelizacja $w$ duchu Soboru Watykańskiego II, vol. I, Katowice 1995, p. 21.

${ }^{6}$ Paul VI, Apostolic Exhortation Evangelii Nuntiandi, 8 December 1975, "Acta Apostolicae Sedis" 68 (1976), 17 (further: AAS).

${ }^{7}$ Paul VI, Apostolic Exhortation Evangelii Nuntiandi, 8 December 1975, AAS 68 (1976), 24.

${ }^{8}$ Cf. Paul VI, Apostolic Exhortation Evangelii Nuntiandi, 8 December 1975, AAS 68 (1976), 41.

9 Cf. Speech of Paul VI to the members of "Concilium de Laicis" (2. X. 1974), AAS 66 (1974), p. 568. 
and teaching them to obey everything I have commanded you. And surely I am with you always, to the very end of the age". ${ }^{10}$ They were to go and teach, i. e. proclaim the message of Salvation with their lives - not only through words, but also through their acts: "As the body without the spirit is dead, so faith without deeds is dead"." They were not left alone, as they were given the Holy Spirit who helped them accomplish that mission. Contemporary catechists are to fulfill the same task Jesus gave to the Apostles. Reinforced by the Holy Spirit, they should proclaim the Resurrected with their own lives in the places to which they were sent by the Church.

What is catechesis? The word originates from the Greek katecheo which originally meant "call from up above" (ex alto) and produce echo (kata - from up, echeo - to sound, to utter). John Paul II explained that the later meaning of this word - to teach - was not to be based on a one-sided message, but on a dialogue including questions and answers. "The voice of a teacher is a conscious echo of the student's question, and the student's question - an echo of the teacher". In Catechesi tradendae we read that "catechesis is an education of children, young people and adults in the faith, which includes especially the teaching of Christian doctrine imparted, generally speaking, in an organic and systematic way, with a view to initiating the hearers into the fullness of Christian life". ${ }^{13}$

In Poland, religious education has been taught at schools since 1990. Within this time, in many educational institutions, lessons of religious education have become school catechesis with the elements of evangelization.

At the moment, the state of epidemic threat has given catechists a special task. They are to take up proper actions and use adequate resources that may help a catechized person to unite with Christ. It makes it possible for teachers to search for new ways of reaching children, youth and their parents that can help them discover the true love and freedom in Christ, which are the foundations to build life based on the system of values flowing from the Gospel.

Therefore, how does evangelization relate to catechesis in the present situation in Poland?

${ }^{10}$ Matthew 28:19-20.

${ }^{11}$ James 2:26.

12 John Paul II, Catechesis at the Beginning of the Church. Wednesday Catechesis (12 XII 1984), in: John Paul II, I believe in God the Father and the Creator, Citta del Vaticano 1987, 13-14.

${ }^{13}$ John Paul II, Apostolic Exhortation Catechesi tradendae, 16 October 1979, AAS 71 (1979), 18. 
John Paul II noted that "there is no separation or opposition between catechesis and evangelization. Nor can the two be simply identified with each other. Instead, they have close links whereby they integrate and complement each other". ${ }^{14}$ Catechesis becomes the "basic activity of evangelization", ${ }^{15}$ which, according to Fr. Tadeusz Panuś $\mathrm{PhD}$, creates new "opportunities for proclaiming the Gospel"16, as it is the "presence of Good News where children and young people's hearts are being shaped" ${ }^{17}$ In the current situation of epidemic threat we are given the space in which, through remote teaching, we can spread the redemptive message not only among the children, but also - through young people - among their parents.

Thus, the presence of catechesis in the media makes it possible for us to take up various activities aiming at the evangelization of the school and family environment. This is particularly important especially when taking into account the danger of the coronavirus (COVID - 19) which is spreading rapidly. Once again, the Church has faced the challenge to bring the Gospel of Christ to the people who cannot participate in Holy Masses or other services because it threatens their health and life. In dangerous situations, such as disease, wars or hunger, the faithful have always gathered to pray together. Today, unfortunately, in most countries of the world, it is impossible. The bishops, who are responsible for Christ's Sheepfold entrusted to them, have issued decrees in which they recommend that people should remain in isolation. The Polish Episcopal Conference emphasized that "taking into account the risk of losing health or life (according to can. $87 \S 1$, can. 1245 and can. $1248 \$ 2$ of the Code of the Canon Law), diocesan bishops are asked to dispense the faithful from the obligation to participate in the Holy Mass until $29^{\text {th }}$ March $2020(\ldots)^{\prime \prime}{ }^{18}$

That is why, the question appears: How, while staying in isolation, can we remain in the community of the Church without neglecting the work of catechesis and evangelization?

${ }^{14}$ John Paul II, Apostolic Exhortation Catechesi tradendae, 16 October 1979, AAS 71 (1979), 18.

${ }^{15}$ Congregation for the Clergy, Dyrektorium ogólne o katechizacji [General Directory on Catechization], Poznań 1997, 218.

${ }^{16}$ T. Panuś, Katechizacja, ewangelizacja, kształtowanie człowieka, "Znak" 9 (2007), p. 5.

${ }^{17}$ T. Panuś, Katechizacja, ewangelizacja, kształtowanie człowieka, op. cit., p. 5.

${ }^{18}$ Cf. The Permanent Council of the Polish Episcopal Conference, Regulation no. 1/2020 of 12 March 2020, https://episkopat.pl/zarzadzenie-nr-1-2020-rady-stalej-konferencjiepiskopatu-polski-z-dnia-12-marca-2020-r/, (17.03.2020). 


\section{Spiritual communion with the Church}

The bishops emphasize that the first and the most important issue addressed to the whole Church is the spiritual communion of the faithful. ${ }^{19}$ According to the people responsible for promoting Christian values, the catechized youth should be assured that, although we are isolated from one another, a Christian is not alone. Each believer is a member of the community united by Christ. The basis of that spiritual community is love: "It is by your love for one another, that everyone will recognise you as my disciples." ${ }^{20}$

This love, first of all, is to lead the faithful to the Eucharist which is the "heart and the summit of the Church's life, for in it Christ associates his Church and all her members with his sacrifice of praise and thanksgiving offered once for all on the cross to his Father; by this sacrifice he pours out the graces of salvation on his Body which is the Church." ${ }^{21}$ While staying at homes, the faithful can spiritually experience the Holy Mass broadcast by the media. Priests and lay catechists should provide the believers with information on how the latter can participate in such a Mass. It is because, until now, the spiritual participation in the Holy Mass and other services was only practiced by the ill and elderly. The present epidemic situation resulted in the fact that the group of spiritual participants in the Eucharist significantly increased. At the moment, the group includes people with the symptoms of an infection, school children and youth, as well as adults who take care of them, and everyone who is afraid of being infected with the virus. ${ }^{22}$

The spokesman for the Polish Episcopal Conference, Fr. Pawel Rytel-Andrianik noted that there are no Church regulations that indicate how the faithful should act during the broadcast of the Eucharist. However, he encouraged them to participate in the celebration, listen to the Word of God, and refrain from doing other things in the house. ${ }^{23}$

19 Cf. The Permanent Council of the Polish Episcopal Conference, Regulation no. 1/2020 of 12 March 2020.

${ }^{20}$ John 13:35.

${ }^{21}$ Catechism of the Catholic Church 1407.

${ }^{22}$ Cf. The Permanent Council of the Polish Episcopal Conference, Regulation no. 1/2020 of 12 March 2020.

${ }^{23}$ Cf. The spokesman of the Polish Episcopal Conference on the participation in broadcast Holy Masses, https://episkopat.pl/rzecznik-episkopatu-o-przezywaniu-transmisji-mszyswietych/ (17.03.2020). 
In the Directory of the Polish Episcopal Conference concerning the celebration of the Eucharist broadcast on television it is emphasized that "liturgical celebration of the Church is performed in the community gathered 'in the name of the Lord'. A characteristic feature of this community is sharing the faith and supporting one another through giving witness. It is only possible when people who are next to one another constitute a real community."24 Thus, during the pandemic, the faithful who take part in the Holy Mass broadcast by the media, should gather in the name of Christ, focusing not only on the image that is being transmitted, but mainly on remaining in the spiritual community with the whole Church. The Polish Episcopate emphasizes that a television broadcast may help people to spiritually receive the Holy Communion. ${ }^{25}$ It is because, as it had already been specified during the Council of Trent in the $16^{\text {th }}$ century, spiritual communion is the communion of spiritual unification with the Saviour, the basis and source of which is the faith. The man who desires the Eucharist experiences its results while uniting with Christ in love. Such a communion is based on a true unification with God despite the lack of the consecrated Host. ${ }^{26}$

Also, Pope Francis encourages the whole Church to receive the spiritual Holy Communion, emphasizing that everyone who participates in the Eucharist through the media can truly experience it. ${ }^{27}$

Therefore, people responsible for catechesis and evangelization, while using the available media, e. g. the Internet, should encourage the faithful to remain in the spiritual communion with the Church through an active participation in broadcast services.

Another aspect directly resulting from the spiritual community of the Church is caring for the weakest: "whatever you did for one of the least of these brothers and sisters of mine, you did for me." ${ }^{28}$ That is why, the tasks of people responsible for catechesis and evangelization should also include encouraging everyone

${ }^{24}$ Directory of the Polish Episcopal Conference concerning the celebration of the Eucharist broadcast on television, Warsaw 2017, 12.

${ }^{25}$ Cf. Directory of the Polish Episcopal Conference concerning the celebration of the Eucharist broadcast on television, Warsaw 2017, 15.

${ }^{26}$ Cf. Council of Trent, Decree on the Most Holy Sacrament of the Eucharist, chapter 2, in: Dokumenty soborów powszechnych [Documents of General Councils], eds. A. Baron, H. Pietras, Kraków 2004, vol. IV, pp. 453-458.

27 Pope Francis, the Holy Mass celebrated in St. Martha's House on 19.03.2020. https:// www.niedziela.pl/artykul/50489/Franciszek-zachecil-do-Komunii-sw (19.03.2020).

${ }^{28}$ Matthew 25:40. 
to "support the elderly and the ones in need. ${ }^{29}$ While making others sensitive to the needs of the weakest, we should emphasize that not only do we owe them prayer and spiritual support, but also, or first of all, we should get involved in the works of mercy which include, e. g. doing shopping, bringing medicine or talking, without risking the contraction of the virus at the same time. We should support the faithful in building the attitude of courage, so that, whilst standing up to fear, they would not neglect the ones from their nearest environment who need them. To do this, people responsible for catechesis and evangelization can use various Internet communication tools, such as Skype, Facebook Messenger, and WhatsApp. However, is a word enough? In the situation of a threat we need the personal involvement of priests and lay catechists in helping others. It is because today people need witnesses more than speakers. ${ }^{30}$

\section{Teaching methods and didactic resources as elements that support the work of evangelization and catechesis in the school environment during the pandemic}

Kindergartens and schools constitute the reality in which a catechist spreads the message of Salvation among children and young people through systematic reinforcement of the contents related to the Gospel and the teaching of the Church. Teaching methods and properly selected didactic resources can help teachers to fulfill this task.

The epidemic situation in the world, especially in Europe, resulted in suspending the educational activities at schools. In Poland, according to the Regulation of the Minister of National Education of 11 March 2020 on the temporal limitation of the functioning of educational units in connection with preventing and fighting COVID-19, educational activities in their traditional form were suspended..$^{31}$ When the document came into force, teachers were encouraged

${ }^{29}$ Cf. The Permanent Council of the Polish Episcopal Conference, Resolution no. 1/2020 of 12 March 2020, https://episkopat.pl/zarzadzenie-nr-1-2020-rady-stalej-konferencjiepiskopatu-polski-z-dnia-12-marca-2020-r/ (17.03.2020).

${ }^{30}$ Cf. Benedict XVI, Be the witnesses of Christ, A letter to youth gathered by the Lednica Lake, Vatican 2.06.2005, "L'Osservatore Romano" 7-8 (2005), p.40.

31 Cf. Regulation of the Minister of National Education of 11 March 2020 on the temporal limitation of the functioning of educational units in connection with preventing and fighting COVID-19, http://dziennikustaw.gov.pl/DU/2020/410 (16.03.2020). 
to teach online. The Commission for Catholic Education of the Polish Episcopal Conference, while expressing its opinion on the present situation in the Polish school, informed Polish teachers of Religious Education working in various educational institutions about different forms of catechesis with the use of, i.a., educational websites and other digital devices enabling remote teaching. ${ }^{32}$

Such a form of teaching may become a school catechesis and it may achieve its proper objective, i. e. the development of faith, only when it is properly adjusted to the recipients: "the age and the intellectual development of Christians, their degree of ecclesial and spiritual maturity and many other personal circumstances demand that catechesis should adopt widely differing methods for the attainment of its specific aim: education in the faith. On a more general level, this variety is also demanded by the social and cultural surrounding in which the Church carries out her catechetical work. The variety in the methods used is a sign of life and a resource." 33

The present situation in Poland and in the world gives teachers the opportunity to search for various forms, methods and didactic resources through which they can catechize and evangelize children and youth while staying at home. Those who are responsible for proclaiming the salvific message are challenged not to focus only on the remote transmission of knowledge, but also, or first of all, on helping a young person discover his/her personal relation with Christ at the time when people's health and lives are threatened.

Because of the circumstances, catechists mainly depend on themselves on their own creativity and ideas. Various multimedia teaching aids can make it easier for them to fulfill their task. Such aids include, e.g. educational films on the Internet, platforms for teachers and students, or multimedia materials published online by Christian publishing houses. However, didactic resources are not enough if we fail to select the proper teaching method and neglect individual contact (despite staying in isolation) with the student.

The proper remote transmission of knowledge can become the yeast mentioned in the Gospel ${ }^{34}$, through which the catechized students, by accessing the proper foundations related to the principles of Christian life, shall be able

\footnotetext{
${ }^{32}$ Cf. A. Rayzacher-Majewska, Zdalne nauczanie religii, https://opoka.news/zdalne-nauczaniereligii?fbclid=IwAR0M83ARB4X1StE0M_BX9QbrNro1jSabx4sFOgeobCuwoLESkTxePPWJ_ SA (16.03.2020).

33 Cf. John Paul II, Apostolic exhortation Catechesi tradendae, op. cit, 51.

${ }^{34}$ Cf. Matthew 13:33.
} 
to join - after the epidemic risk diminishes - the parish life, e. g. through the participation in the Eucharist, receiving holy sacraments or taking part in various services.

We should make sure that, during the school catechesis, online activities are adjusted to the students' level and based on interesting teaching methods that will encourage the students to discover and learn about the contents of the redemptive message..$^{35}$

One of the most important stages of evangelization and catechesis should be the primary school. It is during this period when young people are prepared, first, to receive the sacrament of the Eucharist, and then, to the confirmation. That is why, we have to do our best to create the proper conditions in which children and youth want to get to know and discover Christ.

If the remote primary school lessons of religious education are to become a catechesis, first they should fulfil the basic three objectives: initiation, didactic and upbringing one. Also, we should make sure that what we teach about the Gospel is interesting for young people. The children should be willing to take part in the activities we invite them to. A good example is the lesson prepared by Sister Magdalena Wójcik for the fifth grade of the primary school on the Parable of the Forgiving Father ${ }^{36}$, in which, through the Internet platform, the students are e-mailed a special link. Then, they are to do several activities based on the Parable of the Forgiving Father, ${ }^{37}$ e.g.: listen to the recorded Biblical text, do the crossword, answer a few questions that encourage them to a personal reflection on the subject. The illustration for the activities is the painting by Bartolomé Esteban Murillo: Return of the Prodigal Son. The catechesis also contains a humorous element based on a very short, funny religious film. This way, a remote lesson of Religious Education becomes not only a catechesis with evangelization elements, but also an interesting activity for the students who are encouraged to work on their own, think about their faith, and discover the love of God illustrated by the above-mentioned Biblical parable.

Another educational stage worth emphasizing is secondary school. In this period, young people often experience teenage rebellion during which they search cit., 71 .

${ }^{35}$ Cf. Congregation for the Clergy, Dyrektorium ogólne... [The General Directory...], op.

${ }^{36}$ Cf. M. Wójcik, Przypowieść o miłosiernym ojcu, https://katecheza.diecezja.pl/aktualnosci/ zdalne-nauczanie-pomoce-dla-szkol-podstawowych/, (30.03.2020) with the use of the Internet platform: https://www.thinglink.com/card/1299469695094620161 (30.03.2020)

${ }^{37}$ Cf. Luke 15:11-32. 
for their own place in the world. That is why, if we want to reach them with the message of the Gospel, we must pay special attention to the adjustment of the tools of work to their age. At this stage, it is not enough to make the students interested in what we teach. First, we have to encourage them to discover and find their own ways of reaching Christ. Remote catechesis makes it possible. As an example, we can take the lessons of religious education for the first grade of secondary school, concerning the sacraments. The catechist, on the basis of the apostolic exhortation by John Paul II, Reconciliatio et paenitentia, the painting by Rogier van der Weyden: "The Seven Sacraments Altarpiece", and the exercises that include didactic games, refers to particular pages or educational platforms to encourage the student to develop his/her knowledge on their own and to discover the value of sacramental life..$^{38}$ During such classes, the catechist does not give the student ready-made solutions, but inspires him/her to search for the truth that is to help them discover the values flowing from the redemptive message. It is very valuable from the point of view of evangelization. This way, the school catechesis becomes evangelization that leads to faith and development of the relation with Christ of those who declare they attend religious education lessons although they are non-believers of indifferent to religion. Not only do exercises constructed this way help young people develop their faith, but they also enable them to obtain new information on, e. g. papal teaching and sacred art. The catechist, through proper educational aids, encourages young people to discover, on their own, the meaning of being in the spiritual communion with the Church. Once again, such activities become the source of both catechesis and evangelization.

Remote catechesis and evangelization require commitment and creativity from those who are responsible for it. Catechists and teachers should not only prepare new materials, send exercises to the students and check them, but they also have to encourage children and young people to the common prayer, participation in Holy Masses broadcast through the media, and to the reception of the spiritual Holy Communion.

Also, we need to make young people sensitive to the needs of others, especially those who are old and ill. Contact with those responsible for the work of catechesis and evangelization should not only be limited to transmitting knowledge or reports through Internet tools, such as Skype, Facebook Messenger,

${ }^{38}$ Cf. R. Chrzanowska, Zasady zdalnego nauczania, https://katecheza.diecezja.pl/zdalnenauczanie/, (30.03.2020). 
or WhatsApp. At this difficult time, a catechist should give the students spiritual and psychological support. It is not enough to be a good teacher; a catechist must be a witness of Christ.

Catechesis and evangelization at the time when traditional classes at schools are suspended may be supported by various religious initiatives.

In the Archdiocese of Kraków, one of such actions is the campaign that encourages young people to pray: \#mimoDrzwiZamkniętych [despite closed doors..$^{39}$ In the appeal published on the Facebook page of the Ministry for Youth of the Archdiocese of Kraków, the priests responsible for the formation of youth communities encourage teenagers to pray the Chaplet of the Divine Mercy every day, to share the information on Internet retreats and other initiatives which do not require going out, and, first of all, to support one another in fasting. ${ }^{40}$

Another campaign that supports the work of catechesis includes Internet retreats, e. g. Rekolekcje\#nargłosy [retreat for two voices] ${ }^{41}$, conducted by Fr. Wojciech Węgrzyniak and Fr. Krzysztof Porosło, during which young people can develop their faith and knowledge of the Eucharist. Not only do the retreat priests provide the students with specific information in an interesting manner, but they also give the participants particular challenges related to the time of Lent, e.g.:

- try to make the sign of the cross according to the eastern tradition, with the proper layout of fingers;

- try to greet another person;

- try to reconcile with another person;

- pray for whoever has asked you to pray for them. ${ }^{42}$

Not only does the selection of tasks help the participants of this form of retreat to deepen their faith, but it also makes it possible for them to build a community with others and with Christ.

${ }^{39}$ Duszpasterze młodzieży zachęcaja do modlitwy [Catechists of the Youth Encourage to Pray] \#mimoDrzwiZamkniętych, https://diecezja.pl/aktualnosci/nie-mozemy-zostawicmlodych-samych-duszpasterze-mlodziezy-zachecaja-do-modlitwy-mimodrzwizamknietych/ (19.03.2020).

${ }^{40}$ Cf. Duszpasterze młodzieży zachęcają do modlitwy \#mimoDrzwiZamkniętych, https:// diecezja.pl/aktualnosci/nie-mozemy-zostawic-mlodych-samych-duszpasterze-mlodziezyzachecaja-do-modlitwy-mimodrzwizamknietych/ (19.03.2020).

${ }^{41}$ Rekolekcje \#na2głosy, https://www.youtube.com/watch?v=-NjFkJYhdpI\&list=PLvFXg jwLDFeTWHemJ9Yxx0SnGxXmkWZfJ\&index=3 (19.03.2020).

${ }^{42}$ Rekolekcje \#na2głosy, op. cit. 
There is also an initiative for children aged 6-10, prepared by the community Mocni $w$ Duchu ${ }^{43}$ [The Powerful in the Spirit] which, on the basis of music workshops and the Arena of Youth, prepared interactive meetings based on the Word of God.

During an Internet broadcast that lasts an hour and a half, children learn, i.a. songs, English, and art. Not only do such activities relieve the parents of their obligations, but they are a form of evangelization and catechesis during the time of pandemic.

Religious initiatives that support the work of catechesis usually include the activities of various ministries responsible for spreading the Gospel in the present situation. That is why, it is important to promote these initiatives on the Internet websites of all the dioceses in a given country. It is because in this way, amidst the information overload, promoting additional initiatives supporting religious education can reach not only the catechists who are looking for new forms of teaching, but also a broader group of recipients that includes the catechized ones.

\section{Remote lessons of religious education and the evangelization of family}

The presence of catechesis at school makes it possible to evangelize the students' parents. The family, as the first and basic catechetical environment that influences a person from the moment of birth until death, becomes the model of particular behaviours in which a hierarchy of values is shaped. It influences the catechized ones' social, psychological and religious development. ${ }^{44}$ That is why, through the student, a catechist should also evangelize his/her parents. A teacher should not omit contact with the parents because his/her task is to support the upbringing process oriented at the catechized person ${ }^{45}$ so that the latter can grow in his/her faith. The Holy Father John Paul II said: “The family's catechetical activity has a special character, which is in a sense irreplaceable. This

${ }^{43}$ Mocni w Duchu dzieciom w czasie epidemii korona wirusa [The Powerful in the Spirit For Kids During the Coronavirus Pandemic], https://www.archidiecezja.lodz.pl/2020/03/mocni-wduchu-dzieciom-w-czasie-epidemii-koronawirusa/ (18.03.2020).

${ }^{44}$ Cf. Polish Episcopal Conference, Podstawa programowa... [Core Curriculum...], op. cit., p. 8,32 .

${ }^{45}$ Cf. M. Mendel: Rodzice i nauczyciele jako sprzymierzeńcy, Gdańsk 2007. 
special character has been rightly stressed by the Church, particularly by the Second Vatican Council. Education in the faith by parents, which should begin from the children's tenderest age, is already being given when the members of a family help each other to grow in faith through the witness of their Christian lives, a witness that is often without words but which perseveres throughout a day-to-day life lived in accordance with the Gospel." ${ }^{46}$

Fr. Tadeusz Panuś emphasizes that "school catechesis is definitely the extension of the area of evangelization and the improvement of the quality of ministry in the name of God, but it is also the service of another man." ${ }^{47}$ That is why, we should use the opportunity of remote religious education lessons to proclaim the Gospel contents that would help the students and their families grow in faith.

Evangelization that results from the presence of school catechesis not only includes children and youth, but also their family environment. That is why, it is worth making sure that the student who participates in remote learning of religious education becomes "the voice of the catechist" during the pandemic - the person who helps everyone in the family to cope with the threat of pandemic, who encourages the family members to everyday family prayer, and to the participation in the services broadcast through the media.

\section{Conclusions}

Evangelization is the process in which the task of the Church, which acts through the power of the Holy Spirit, is to proclaim the Good News of the Father's salvific plan to the whole world. That is why, it is worth to briefly recall some aspects. "The basic element of evangelization is the service of the word, although it does not exhaust the whole reality of evangelization. Evangelization is carried out through deeds and words. It is simultaneously a witness and proclamation, a word and a sacrament, teaching and commitment." ${ }^{38}$

In catechesis, evangelization should be carried out through:

- proclamation, during which the catechist is the one who spreads the

\footnotetext{
${ }^{46}$ John Paul II, Apostolic exhortation, Catechesi tradendae, op. cit., 68.

${ }^{47}$ T. Panuś, Katechizacja, ewangelizacja, kształtowanie człowieka, "Znak” no. 628 (2007), p. 6.

${ }^{48}$ Polish Episcopal Conference, Dyrektorium katechetyczne Kościoła katolickiego w Polsce [The Catechetical Directory of the Catholic Church in Poland], op. cit., 54.
} 
Good News. The catechist is compared to a herald, and catechesis itself - to his/her appeal;

- gathering of a group in which the catechist plays the role of a moderator;

- attraction in which the catechesis becomes a unique offer for young people, where the catechist is an authority;

- radiation in which the catechist becomes a witness or a guide. In such an approach, the catechesis is the presentation of the Christian mystery;

- "infecting" based on evangelization, which resembles the "chain reaction";

- "leavening" which is particularly visible in the phenomenon of inculturation. ${ }^{49}$

Such evangelization present within catechesis is to lead a person to faith, to internal transformation, and to the change of thinking. That is why, during the present situation of epidemic threat, it is so important for catechesis to take place in the school and family environment. It makes it possible to proclaim the salvific message in the environments that had been neglected in terms of upbringing. It can lead the catechized ones, as well as their parents and relatives, to the reflection on the Gospel.

A school lesson of religious education can become the place for evangelization and catechesis, being a clear sign of faith as a part of the man's culture, knowledge and personality..$^{50}$ It is because, by making the first step, a young person "recognizes faith as an element that is surprising and interesting at the same time. He/she often wants to do the next step for which the reality outside the school is the proper place. The person starts looking for some groups, communities, ministries or the parish catechesis that prepares people to receive the sacraments." ${ }^{\prime 1}$

A remote lesson of religious education can be the school catechesis that develops the students' knowledge and faith. It also gives the teachers a unique

${ }^{49}$ J. Kochel, Wymiar ewangelizacyjny katechezy szkolnej [in]: Katecheza ewangelizacyjna, poszukiwania koncepcji, ed. P. Mąkosa, Lublin 2010, pp. 46-47. On the concept of evangelization with reference to the teaching of Jesus, see also: C. M. Martini, Alzati, và a Ninive, la grande città! Lettera ai pastorali e alla comunità della città sulla evangelizzazione, Milano 1991, pp. 8-9.

${ }^{50}$ Cf. A. Kielian, Modele nauczania religii rzymskokatolickiej w krajach europejskich, Kraków 2010, pp. 213-219.

${ }^{51}$ T. Słomiński, Katecheta w szkole. Przestrzeń do zabudowania, “Katecheta” 4 (2005), p. 55. 
opportunity to evangelize both the students and their parents within the school environment. That is why, evangelization campaigns in the mass media should support the catechists' difficult, everyday remote work with their students. Such campaigns often refer to young people's experience, due to which they can intensify the evangelization influence on children and youth. The fact that religious education is taught at schools makes it possible to access all the students, including those who had been neglected in terms of upbringing or religious knowledge. While building the space in which Christian values are promoted, teachers of religious education - not only through the regular transfer of knowledge within the school catechesis, but also through the introduction of various activities on educational platforms or joining evangelization campaigns together with the catechized ones - help young people discover the love of Christ during this difficult time of isolation.

The epidemic threat caused by the coronavirus has forced the whole community of the Church to face specific challenges. Catechesis and evangelization were given a new chance and, at the same time, a task to encourage the faithful to keep the spiritual contact with the Church through the use of the media. Traditional teaching during the pandemic has to be replaced with the proper media broadcast that shall not only be based on the proclamation of the salvific message, but that will also help particular people feel the sense of the community the head of which is Christ. That chance was already recognized by the council fathers who participated in the Second Vatican Council and who, already in 1963 , encouraged us to use the mass media in an efficient manner, i. e. to adjust them to particular circumstances, situations and time. They also emphasized the role of religious leaders in such application of the media: "It is the duty of Pastors to instruct and guide the faithful so that they, with the help of these same media, may further the salvation and perfection of themselves and of the entire human family". ${ }^{2}$ Circumstances, matters and time in the situation of the pandemic are difficult. However, they cannot make a believer feel lonely and separated from the community of the Church. That is why, we need wise people responsible for the work of catechesis and evangelization - people who are able to face the challenge building specific spaces in which all people, both the young and the older ones, will be able to encounter the Saviour.

${ }^{52}$ Cf. Dekret o środkach społecznego przekazu Inter mirifica [Decree on the Media of Social Communications Inter Mirifica], in: Sobór Watykański II. Konstytucje, dekrety, deklaracje [II Vatican Council. Constitutions, Decrees, Declarations]: Polish text, new translation, 1st edition, Poznań 2002, pp. 87-95. 


\section{Bibliography}

The Old and New Testament Bible, 5th edition, Biblia Tysiaclecia, Poznań 2000.

Catechism of the Catholic Church, 2nd edition, Poznań 2012.

Council of Trent, Decree on the Most Holy Sacrament of the Eucharist, chapter 2, in: Dokumenty soborów powszechnych, ed. A. Baron, H. Pietras, Kraków 2004, vol. IV, pp. 453-458.

II Vatican Council, Decree on the Media of Social Communications Inter Mirifica, in: Sobór Watykański II. Konstytucje, dekrety, deklaracje: Polish text, new translation, 1st edition, Poznań 2002, pp. 87-95.

II Vatican Council, Declaration on Christian Education Gravissimum educationis, 5, in: Sobór Watykański II. Konstytucje, dekrety, deklaracje, Poznań 2002, pp. 314-324.

John Paul II, Apostolic exhortation Catechesi tradendae, 16 October 1979, AAS 71 (1979).

Paweł VI, Apostolic exhortation Evangelii Nuntiandi, 8 December 1975, "Acta Apostolicae Sedis" 68 (1976).

Directory of the Polish Episcopal Conference concerning the celebration of the Eucharist broadcast on television, in: Acts of the Polish Episcopal Conference 29 (2017).

Congregation for the Clergy, The General Directory on Catechization, Poznan 1997.

Polish Episcopal Conference, The Catechetical Directory of the Catholic Church in Poland, Kraków 2001.

Polish Episcopal Conference, The Core Curriculum for the Catechesis of the Catholic Church, Kraków 2001.

The Commission for Catholic Education of the Polish Episcopal Conference, The Curriculum for Teaching Roman Catholic Religious Education in Schools and Preschools, Kraków 2001.

Baczyński A., Telewizja jako środek ewangelizacji, Kraków 1997.

Benedict XVI, Be the witnesses of Christ, A letter to youth gathered by the Lednica Lake, Vatican, 2.06.2005, "L'Osservatore Romano" 7-8 (2005), p.40.

Clarke A., E-learning nauka na odległość, Warszawa 2007.

John Paul II, Catechesis at the Beginning of the Church. Wednesday Catechesis (12.12. 1984), in: John Paul II, I believe in God the Father and Creator, Citta del Vaticano 1987, pp.10-15.

Kielian A., Modele nauczania religii rzymskokatolickiej w krajach europejskich, Kraków 2010.

Kochel J., Wymiar ewangelizacyjny katechezy szkolnej, in: Katecheza ewangelizacyjna, poszukiwania koncepcji, ed. P. Mąkosa, Lublin 2010, pp.41-50.

Lewek A., Nowa ewangelizacja w duchu Soboru Watykańskiego II, vol. I, Katowice 1995. Łabendowicz S., Techniki multimedialne w katechezie, "Zeszyty Formacji Katechetów" 56 (2014) no. 4, pp. 96-104. 
Martini C.M., Alzati, và a Ninive, la grande città! Lettera ai pastorali e alla comunità della città sulla evangelizzazione, Milano 1991.

Mąkosa P., Technologia informacyjna $w$ dydaktycznym procesie nauczania religii. "Roczniki Teologiczne" no. 53 (2006), pp. 113-130.

Mendel M., Rodzice i nauczyciele jako sprzymierzeńcy, Gdańsk 2007.

Panuś T., Katechizacja, ewangelizacja, kształtowanie człowieka, “Znak”, no. 628 (2007), pp. 5-15.

Penkowska G., Meandry e-learningu. Warszawa, 2010.

Pisarek M., Możliwości i ograniczenia ewangelizacyjnego wykorzystania mass mediów w świetle nauczania papieża Franciszka. “Zeszyty Formacji Katechetów” R. 14 (2014) no. 2(54), pp. 10-19.

Pisarek M., Rola edukacji cyfrowej $w$ dydaktyce nauczania religii, in: XXV lat nauczania religii w polskiej szkole. Między nadzieją a rzeczywistością, ed. M. Zając, Lublin 2015, pp. 291-300.

Pope Francis, Holy Mass celebrated at St. Martha's House, on 19.03.2020. https://www. niedziela.pl/artykul/50489/Franciszek-zachecil-do-Komunii-sw (19.03.2020).

Środki audiowizualne w katechezie. nauczania religii w polskiej szkole, ed. S. Kulpaczyński, Lublin 2004.

Wedeł-Domaradzka A., Raczyńska A., Jak skutecznie prowadzić zajęcia na platformie edukacyjnej?, Warszawa 2013. 